\title{
Reduction of Cadmium Uptake of Rice Plants Using Soil Amendments in High Cadmium Contaminated Soil: A Pot Experiment
}

\author{
Dian Siswanto ${ }^{1}$, Parinda Suksabye ${ }^{2}$, Paitip Thiravetyan ${ }^{3 *}$ \\ ${ }^{1}$ Biology Department, Faculty of Mathematics and Natural Sciences, Brawijaya University, Indonesia \\ ${ }^{2}$ Department of Environmental Science, Faculty of Science and Technology, Suan Dusit Rajabhat University, Thailand \\ ${ }^{3}$ Division of Biotechnology, School of Bioresources and Technology, King Mongkut's University of Technology \\ Thonburi, Thailand
}

\begin{abstract}
The aims of this study were to investigate the effect of agricultural residues on reducing cadmium uptake in rice plants. The rice plants growing on no cadmium/free cadmium soils $(\mathrm{N}), \mathrm{Cd}$ soils $(\mathrm{Cds})$, and $\mathrm{Cd}$ soils each amended with $1 \% \mathrm{w} / \mathrm{w}$ of coir pith $(\mathrm{CP})$, coir pith modified with sodium hydroxide

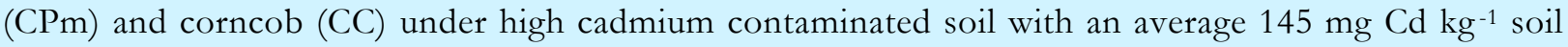
were investigated. The results showed that the cumulative transpiration of rice grown in various treatments under high cadmium contaminated soil followed the order: $\mathrm{Cds}>\mathrm{CPm} \geq \mathrm{CP} \geq \mathrm{CC}$. These transpirations directly influenced cadmium accumulation in shoots and husks of rice plants. The CC and $\mathrm{CP}$ seemed to work to reduce the cadmium uptake by rice plants indicated by accumulated cadmium in the husk that were 2.47 and $7.38 \mathrm{mg} \mathrm{Cd} \mathrm{kg}^{-1}$ dry weight, respectively. Overall, transpiration tended to drive cadmium accumulation in plants for rice grown in high cadmium contaminated soil. The more that plants uptake cadmium, the lower cadmium that remains in the soil.
\end{abstract}

Keywords: transpiration, cadmium uptake, rice plant, agricultural residues

\section{INTRODUCTION}

The study concerned in the rice-based agricultural system on Mae Sot District, Thailand reported that the area contained natural $\mathrm{Zn}-\mathrm{Cd}$ silicate ore which caused the total cadmium in soil to have wide ranges from 0.5 to $284 \mathrm{mg} \mathrm{Cd}$ $\mathrm{kg}^{-1}$ soil with most of them higher than European Economic Community (EEC) maximum permissible level for cadmium soil concentration of $3.0 \mathrm{mg} \mathrm{Cd} \mathrm{kg}{ }^{-1}$ soil. Most of the cadmium concentrations of grain yielded from rice farming ranged from 0.05 to $7.7 \mathrm{mg} \mathrm{Cd} \mathrm{kg}^{-1}$ dry weight which is higher thanthe Thai standardof $0.15 \mathrm{mg} \mathrm{Cd} \mathrm{kg}{ }^{-1} \mathrm{dry}$ weight. As a consequence, theestimation values of weekly in-take (WI) of cadmium from people living around the area ra-

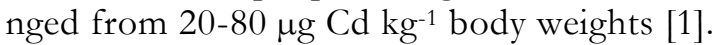

Rice is a staple food that is rich in cadmium with the potential to cause negative health effects such as diarrhea, stomach pains, and severe

\footnotetext{
${ }^{*}$ Corresponding Address:

Paitip Thiravetyan

Division of Biotechnology, School of Bioresources and

Technology, King Mongkut's University of Technology Thonburi, Thailand

E-mail: paitip.thi@kmutt.ac.th
}

vomiting, bone fractures, reproductive failure and possibly even infertility, damage to the central nervous system, damage to the immune system, psychological disorders, DNA damage or cancer development [2]. Cadmium not only causes chronic and acute effects to humans and animals as plant consumers but also disturbs plants themselves. A summary from many researchers and authors [3] stated that cadmium induced the inhibition of root $\mathrm{Fe}$ (III) reductase which led to Fe (II) deficiency and, finally, it seriously affected photosynthesis and/or caused chlorosis. Cadmium toxicity could also affect the plasmamembrane permeability which causes reduction in water content.

Considering the disturbing cadmium effects on humans, animals and plants, a solution is urgently needed to solve the problem of cadmium contamination on soil and irrigation water in rice farming, especially in high cadmium contaminated areas. The conversion of rice farming to other non-food plant farming can be an alternative solution, but in fact, farmers prefer to continue rice farming than change to one of the suggested non-food plants. The conventional approaches which aim to remove heavy metals from soil using several technologies including 
chemical precipitation, membrane filtration, reverse osmosis, ion exchange, and adsorption can be done but most of them are inefficient and expensive. On the other hand, one of the modern techniques that can be adapted to solve this problem is the aided phytostabilization technique $[4,5]$.

The aided phytostabilization technique emphasizes to immobilize or fix metals in soil which uses plant root absorption as the secondary role and soil amendment adsorption as the first role. This technique aims not to remove metal contaminants from a site, but rather to hold them in the soil; therefore, the risk to human health and the environment can be reduced by reducing metal mobility by rhizosphere-induced absorption, and precipitation processes $[4,5,6]$. Biomass raw materials used as amendments in this technique can be from agricultural residues which are abundant such as coir pith and corncob. Moreover, the enhanced adsorption capacity of the amend-ments was also studied focusing on biomass modification [7, 8, 9].

Investigation and development of agricultural residues to adsorb metal ions or other contaminants in aqueous solutions have been done by many researchers $[10,11,12,13,14,15]$ but a few studies have been conducted on the application of adsorbent on the plant-soil system. The aims of this study were to investigate whether a variety of agricultural residues as soil amendments reduced $\mathrm{Cd}$ uptake of rice plants in high cadmium contaminated soil.

\section{MATERIALS AND METHODS}

\section{Preparation of agricultural residues for soil amendment}

There were three kinds of agricultural residues which have been used as soil amendments involving coir pith (CP), corn corb (CC), and coir pith modification (CPm). CP and CC have been available as remediation laboratory properties where the initial sources came from companies from Prachuapkhirikan and Bangkok provinces; however, CPm was prepared in this study. CPm was made from CP modified with $0.1 \mathrm{NaOH}$ as follows: $300 \mathrm{~g}$ of $\mathrm{CP}$ was mixed with $3000 \mathrm{~mL}$ of $0.1 \mathrm{M} \mathrm{NaOH}$ for 2 hours. After treatment with $0.1 \mathrm{M} \mathrm{NaOH}$, the excess $\mathrm{NaOH}$ from treated coir pith was washed with tap water until the $\mathrm{pH}$ was constant (7.75) [8].

\section{Culturing rice plants}

The rice variety that was used was known as 75 days rice. This variety is usually harvested af- ter 65-75 days in the field. Scientific information of the rice is not provided because this variety seems to be under a development project. Rice seeds were soaked with tap water for 1 day and spread on normal soil. After 40 days of seeding, rice plants were transferred to pots.

\section{Effect of agricultural residues on plant transpiration growth under high cadmium contaminated soil}

The relationship between cumulative transpiration and plant cadmium uptake on soil amendment treatments were investigated. 40 day rice plants were used as the test plants. After preparation of the media which contained $700 \mathrm{~g}$ of solid materials mixed with $350 \mathrm{~mL}$ tap water, 2 rice plants were cultured in the media. After one day of incubation, $200 \mathrm{~mL}$ water was added into the experimental pots.

The combination of treatments for solid media were as follows: no cadmium/free cadmium soil $(\mathrm{N})$ as the control, cadmium soil (Cds), Cds with CP $1 \%$ (w/w), Cds with CPm 1\% (w/w) and Cds with CC 1\% (w/w). The serial pot was made into three replicates for 50 days of observation. Pot media without plants were also provided as blanks which were made into three replicates. Transpiration was measured as water was lost from the plants every three to five days by weighing the blank and treated pots. This was done by following the modified gravimetric method [16], but the values were converted into milliliter units by multiplying by the water specific density.

\section{Determination of cadmium distribution in plants}

The plants were separated into two different parts, as roots and shoots (seeds were included). Both of them were dried at $60{ }^{\circ} \mathrm{C}$ for 48 hours. Then, they were burned in an electric muffle at $450{ }^{\circ} \mathrm{C}$ for 2 hours. Plant samples were digested with $65 \%$ of $\mathrm{HNO}_{3}$ and $95-97 \%$ of $\mathrm{H}_{2} \mathrm{SO}_{4}$ and then furthermore analyzed by Inductive Coupled Plasma Spectroscopy (ICP). The concentration was reported in $\mathrm{mg} \mathrm{kg}^{-1}$ of the dry weight.

\section{Determination of remaining cadmium in soil}

Soil samples were dried at $60{ }^{\circ} \mathrm{C}$ for 48 hours and then ground. Samples were digested with 65 $\%$ of $\mathrm{HNO}_{3}$ and $95-97 \%$ of $\mathrm{H}_{2} \mathrm{SO}_{4}$ and then furthermore analyzed by ICP. The concentration was reported in mg kg-1 of the dry weight. 


\section{Statistical analysis}

Analysis of variance (ANOVA) with the Tukey test and correlation test were determined using the SPSS Program for Windows.

\section{RESULTS AND DISCUSSION}

Effect of agricultural residue additions in high cadmium contaminated soil on transpiration, dry weight and cadmium (cd) uptake in rice plants

To confirm the ability of CC, CPm and CP to reduce cadmium uptake in rice plants, the effect of these agricultural residues was investigated in rice grown under high cadmium concentrations. The initial cadmium concentration in contaminated soil was in the range of 96.26 to $215 \mathrm{mg} \mathrm{Cd}$ $\mathrm{kg}^{-1}$ soil with an average of $145.01 \mathrm{mg} \mathrm{Cd} \mathrm{kg}{ }^{-1}$ soil. The addition of agricultural residues affects the transpiration of rice grown under high cadmium concentrations; therefore, the treated rice transpired water in different levels which were in the following order: $\mathrm{CPm} \geq \mathrm{CP} \geq \mathrm{CC}$ (Figure 1). They were similar to rice transpiration grown under low cadmium concentratiosn which were in the following order: $\mathrm{CPm}>\mathrm{CP}>\mathrm{CC}$ (data not shown).

Previous research reported that the low cadmium concentration of soil that is equivalent to a range of 0.11 to $0.56 \mathrm{ppm}$ can retard root growth without toxic effects in leaves resulting in increased transpiration [17]. Transpiration of rice grown in normal soil indicated that the plant metabolism reached the optimal level because
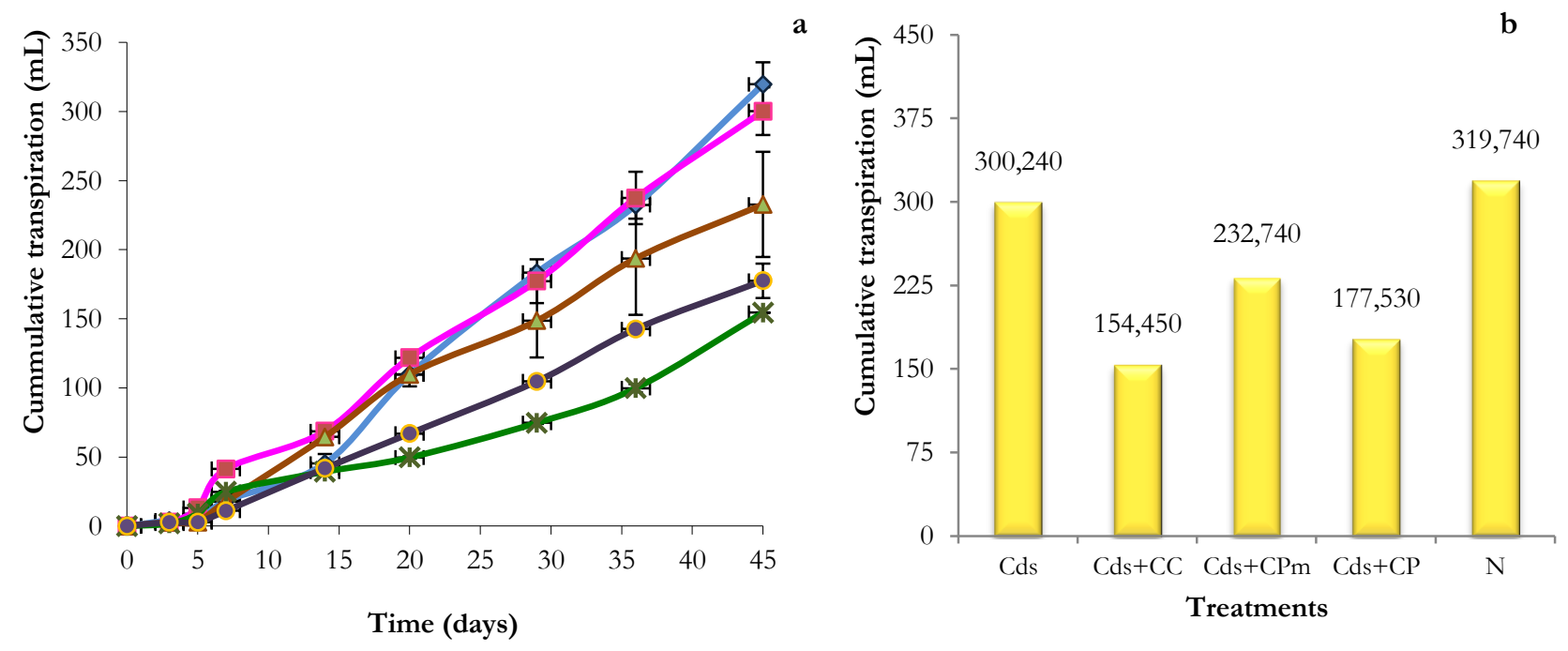

there were no stress conditions. Therefore, the transpiration value was the highest (Figure 1 and 2). Contrarily, rice grown in Cds was assumed in metal stress conditions. High transpiration values probably indicated the defense mechanism of plants from high cadmium accumulation in its organs by such kinds of continuous dilutions; therefore, plants could minimize the toxic effects of cadmium. However, the detailed mechanism to explain the increase of transpiration affected by higher cadmium accumulation is still unclear.

The cumulative transpiration of rice grown in various treatments under high cadmium contaminated soil was in the following order: $\mathrm{Cds}>$ $\mathrm{CPm} \geq \mathrm{CP} \geq \mathrm{CC}$ (Figure 2). These transpiration values affected cadmium accumulations in the shoots which were in the following order: $\mathrm{Cds}>$ $\mathrm{CPm} \geq \mathrm{CP} \geq \mathrm{CC}$ and cadmium accumulations in the husk which were in the following order: $\mathrm{Cds}$ $=\mathrm{CPm}>\mathrm{CP}>\mathrm{CC}$ (Table 1 and Figure 3). By considering these results, $\mathrm{CP}$ and $\mathrm{CC}$ seemed to work in reducing the cadmium uptake by rice plants.

The cadmium movement from soil to roots and from roots to shoots of rice grown in high cadmium contaminated soil seemed to be influenced by the end product compounds of agricultural residue degradation by soil microbial activity. It was assumed that the end products of degradation contained high and low molecular the presence of humic acid (HA), as an example of a high molecular weight compound, decreased the

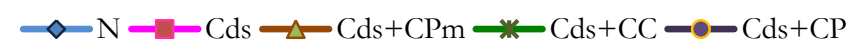

Figure 1. Cumulative transpiration of rice plants $(\mathrm{P})$ grown in no cadmium/free cadmium soil (N) and high cadmium contaminated soil (Cds) in 45 days (a) and under various treatments: (CC: corncob, CPm: modified coir pith and CP: coir pith) (b). Note: Values followed by the same notation indicate that there is no significant difference $(\alpha=$ $0.05)$ 
Table 1. Cumulative transpiration, dry weight and cadmium concentration of rice plants grown in high cadmium contaminated soils (Cds) under various treatments

\begin{tabular}{|c|c|c|c|c|c|}
\hline \multirow[b]{2}{*}{ Treatments } & \multirow{2}{*}{$\begin{array}{c}\text { Cumulative } \\
\text { transpiration at } \\
45^{\text {th }} \text { day }(\mathrm{mL})\end{array}$} & \multirow{2}{*}{$\begin{array}{l}\text { Dry weight of } \\
\text { plant }(\mathrm{g})\end{array}$} & \multicolumn{3}{|c|}{ Rice cadmium concentration at $50^{\text {th }}$ day ( $\left.\mathrm{mgCd} / \mathrm{kgDW}\right)$} \\
\hline & & & Root & Shoot & Husk \\
\hline Cds & $300.24 \pm 17.31 \mathrm{c}$ & $0.991 \pm 0.233 \mathrm{a}$ & $594.324 \pm 40.597 \mathrm{~b}$ & $73.878 \pm 21.10 \mathrm{~d}$ & $13.55 \pm 1.66 \mathrm{c}$ \\
\hline $\mathrm{Cds}+\mathrm{CC}$ & $154.45 \pm 12.52 \mathrm{a}$ & $0.626 \pm 0.131 \mathrm{a}$ & $139.651 \pm 37.315 \mathrm{a}$ & $11.071 \pm 3.70 \mathrm{ab}$ & $2.47 \pm 0.82 \mathrm{a}$ \\
\hline $\mathrm{Cds}+\mathrm{CPm}$ & $232.74 \pm 38.08 \mathrm{~b}$ & $0.747 \pm 0.112 \mathrm{a}$ & $919.328 \pm 226.922 \mathrm{bc}$ & $40.47 \pm 3.96 \mathrm{c}$ & $15.63 \pm 3.10 \mathrm{c}$ \\
\hline $\mathrm{Cds}+\mathrm{CP}$ & $177.53 \pm 0.18 \mathrm{ab}$ & $0.780 \pm 0.145 \mathrm{a}$ & $1188.996 \pm 246.429 \mathrm{c}$ & $37.16 \pm 10.11 \mathrm{bc}$ & $7.38 \pm 0.77 \mathrm{~b}$ \\
\hline
\end{tabular}

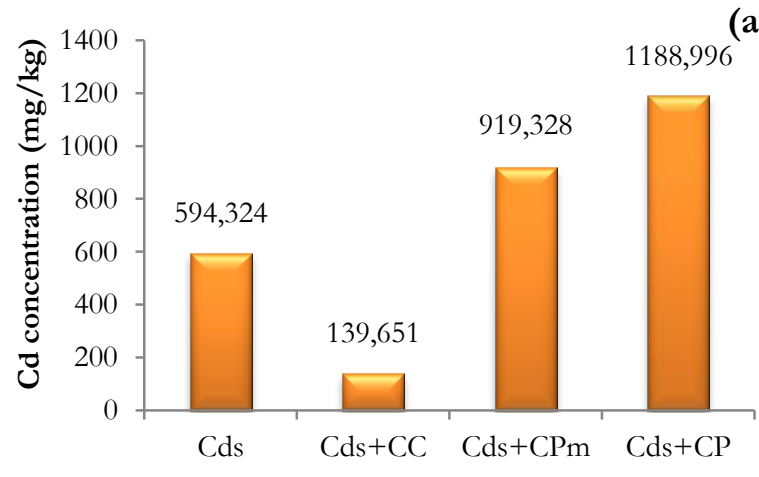

Treatments

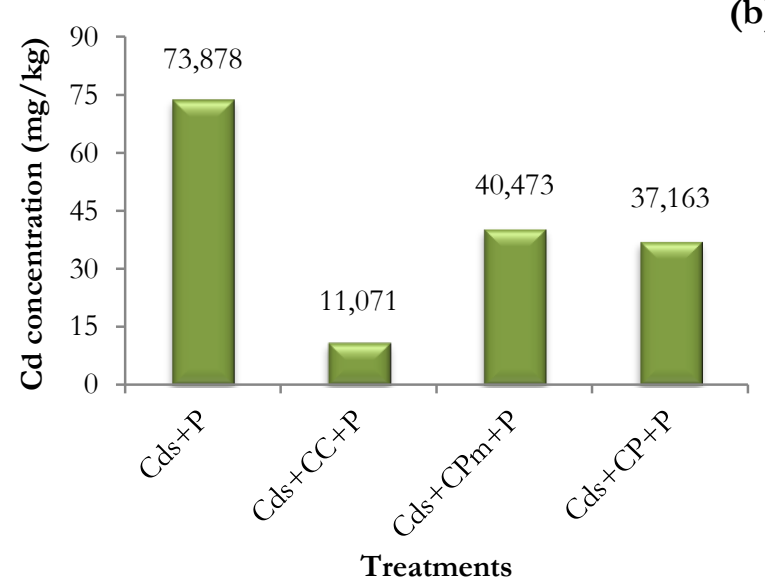

(c)

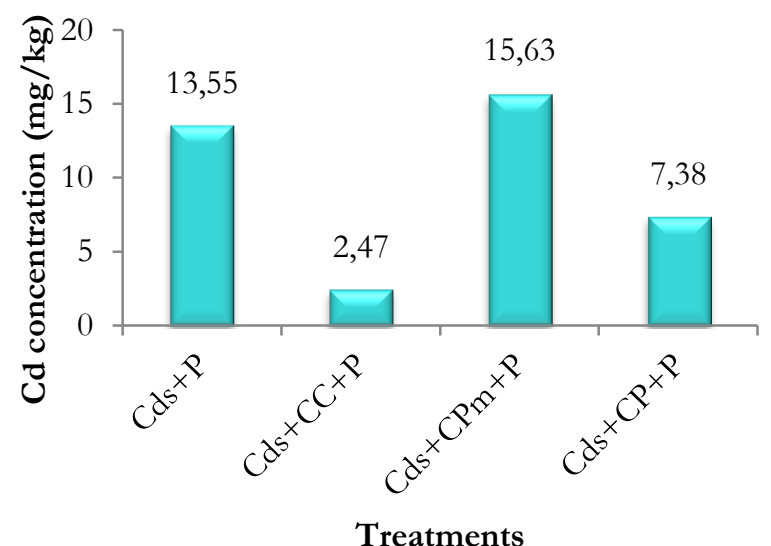

Figure 3. Cadmium concentration of the rice plants grown in high cadmium contaminated soil $(\mathrm{Cds})$ under various treatments: (CC: corncob, CPm: modified coir pith and CP: coir pith). Values followed by the same notation above the bar indicate that there is no significant difference $(\alpha=0.05)$. Root (a), shoot (b), and husk (c).

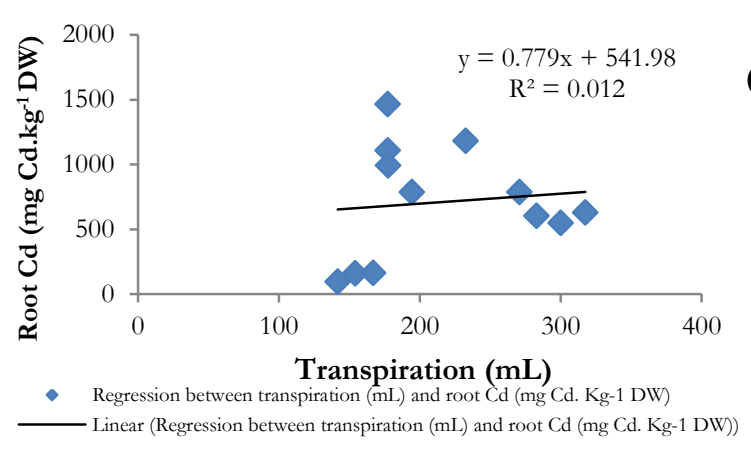

(a)

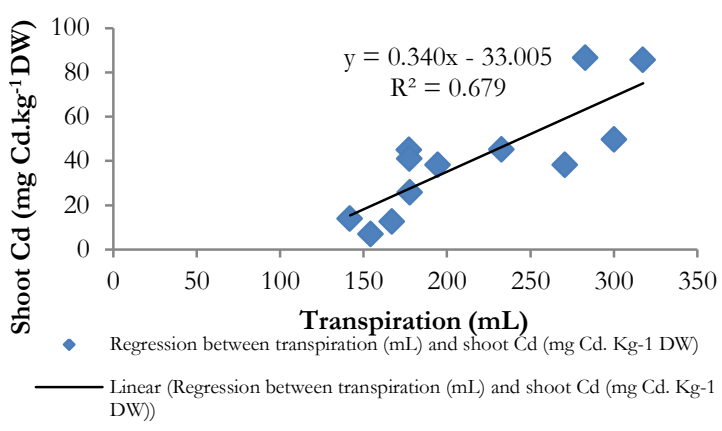

(b)

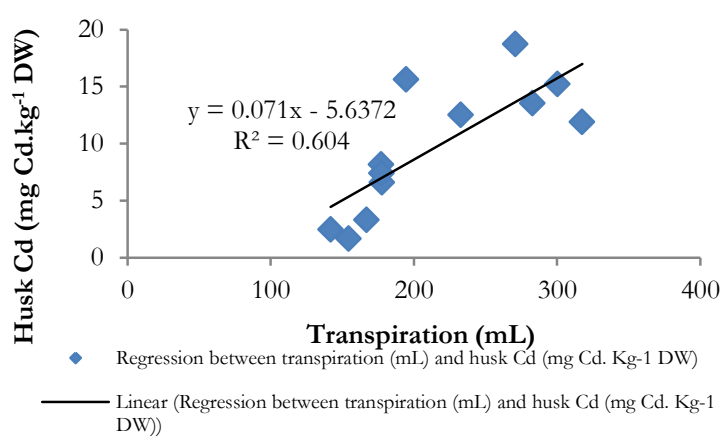

(c)

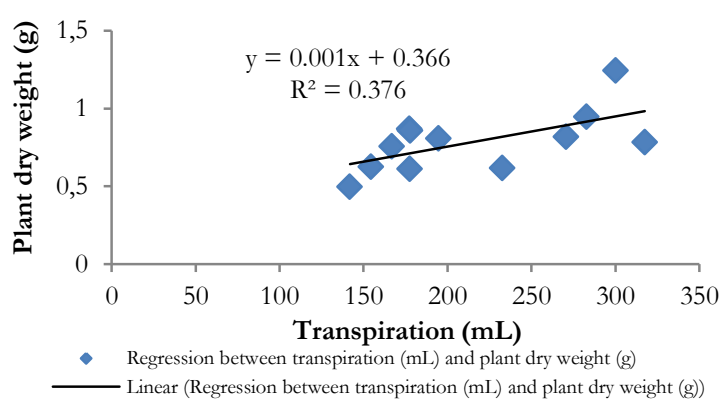

(d)

Figure 4. Regression between transpiration and plant cadmium and between transpiration and plant dry weight under high cadmium soil root $\mathrm{Cd}$ (a), shoot Cd (b), husk Cd (c), and plant dry weight (d) 
uptake of $\mathrm{Cd}$ in the root on the base of total $\mathrm{Cd}$ concentration and free $\mathrm{Cd}$ ion activity. Two reasons may explain the decrease in the uptake of Cd. First, the reduced availability of cadmium may be due to complexation with $\mathrm{HA}$, where insoluble precipitates are furthermore formed.

Second, the HA was adsorbed on the root surface and decreased the uptake sites for internalization of $\mathrm{Cd}$, and thus decreased the uptake of Cd. Contrarily, [18] it was also argued that citric acid (CA), the small organic ligand as an example of a low molecular weight compound, increased the uptake and internalization of $\mathrm{Cd}$. There are many reasons for this to be related. First, the dissociation of the Cd-citrate complex supplied free $\mathrm{Cd}$ ions on the root surface. Second, adsorbed citrate on the xylem cell wall had complexation with $\mathrm{Cd}$; thus, the adsorbed citrate decreased $\mathrm{Cd}$ transferring to the cytosol. Third, the increased $\mathrm{pH}$ decreased the competition of $\mathrm{H}^{+}$with $\mathrm{Cd}^{2+}$ for the uptake sites on the surface root and enhanced the uptake of $\mathrm{Cd}$.

The relationship between transpiration and accumulation of cadmium in the plant organs showed that transpiration mainly increased plant cadmium concentration in shoots and husks with the Pearson correlations 0.824 and 0.778, respectively (Figure 4 and Table 2).

Based on the dry weight measurement of rice grown under various treatments, it is assumed that the rice variety used in this experiment, namely 75 days rice, is a resistant variety of cadmium contamination. There was no significant difference among the dry weights of rice grown in all treatments.

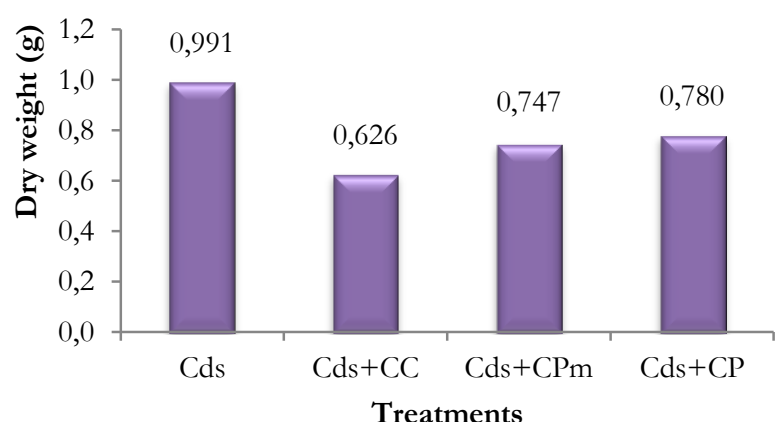

Figure 5. Total dry weight of $50^{\text {th }}$ day rice plants grown in high cadmium contaminated soil (Cds) under various treatments: (CC: corncob, CPm: modified coir pith and CP: coir pith). Values followed by the same notation above the bar indicate that there is no significant difference $(\alpha=0.05)$

Plant resistance might come from many defense mechanisms in plants. Besides producing phytochelation that restricts cadmium just in the roots and inhibiting its movement to the shoots, plants also produce exudates as a defense mechanism to prevent cadmium from entering into the plant roots. Root secretion includes organic ligands and inorganic ligands (e.g., $\mathrm{Cl}^{-}, \mathrm{SO}_{4}{ }^{2-}$, $\mathrm{NH}^{4+}, \mathrm{CO}_{3}{ }^{2-}, \mathrm{PO}_{4}^{3-}$, etc.). These substances function not only as the energy source of microorganisms, but also as ligands to be chelated with heavy metal ions and then influence the $\mathrm{pH}$ and Eh conditions as well as chemical characteristics in the rhizosphere [19].

Table 2. Correlation between transpiration with plant cadmium and plant dry weight of rice grown in high cadmium contaminated soil

\begin{tabular}{lcc}
\hline & \multicolumn{2}{c}{ Transpiration } \\
& $\begin{array}{c}\text { Pearson } \\
\text { correlation }\end{array}$ & Sig. \\
\hline Transpiration & 1 & \\
Husk Cd & $0.778^{* *}$ & 0.003 \\
Shoot Cd & $0.824^{* *}$ & 0.001 \\
Root Cd & 0.111 & 0.732 \\
Plant dry weight & $0.613^{*}$ & 0.034 \\
\hline
\end{tabular}

\section{CONCLUSION}

The results showed that the cumulative transpiration of rice grown in various treatments under high cadmium contaminated soil was in the following order: $\mathrm{Cds}>\mathrm{CPm} \geq \mathrm{CP} \geq \mathrm{CC}$. These transpiration values directly influenced cadmium accumulation in shoots and husks of rice plants. The CC and $\mathrm{CP}$ seemed to work to reduce the cadmium uptake by rice plants indicated by accumulated cadmium in the husk that were 2.47 and $7.38 \mathrm{mg} \mathrm{Cd} \mathrm{kg}^{-1}$ dry weight, respectively. Overall, transpiration tended to drive cadmium accumulation in plants for rice grown in high cadmium contaminated soil. It was shown that the higher the plant uptake of cadmium, the lower remaining cadmium that was found in the soil.

\section{REFERENCES}

1. Simmons RW, Pongsakul P, Saiyasitpanich D, Klinphoklap S (2005) Elevated levels of cadmium and zinc in paddy soils and elevated levels of cadmium in rice grain downstream of a zinc mineralized area in Thailand: Implication for public health. Environmental Geochemistry and Health 27: 501-511.

2. Kumbar SK (2011) Cadmium poisoning, http://eco.neterect.co.in/. Accessed date: September 30, 2011. 
3. Benadives MP, Galleo SM, Tomaro ML(2005) Cadmium toxicity in plants. Brazilian Journal Plant Physiology 17(1): 21-34.

4. Alvarenga P, Goncalves AP, Fernandes RM, de Varennes A, Vallini G, Duarte E (2009) Organic residues as immobilizing agents in aided phytostabilization: (I) Effect on soil chemical characteristics. Chemosphere 74: 1292-1300.

5. Volesky B (2001) Detoxification of metal-bearing effluent: Biosorption for the next century. Hydrometallurgy 59: 203-216.

6. Prasad MNV, Freitas HMDO (2003) Metal hyperaccumulation in plants-Biodiversity prospecting for phytoremediation technology. Electronic Journal of Biotechnology 6 (3): 285-321.

7. Abbas A, Munir M, Aslam F, Naheed S, Zafar, A (2010) Removal of chromium (IV) by biosorption using different agricultural byproducts of some important cereal cropsas biosobents. Middle-East of Journal of Scientific Research6 (5): 512-516.

8. Ewecharoen A, Thiravetyan P, Nakbanpote W (2008) Comparison of nickel adsorption from electroplating rinse water by coir pith and modified coir pith. Chemical Engineering Journal137: 181-188.

9. Sha L, Xue-yi G, Ning-chuan F, Qing-hua T (2010) Effective removal of heavy metals from aqueous solutions by orange peel xanthate. Trans. Nonferrous Met. Soc. China 20: 187-191.

10. Suksabye P, Worasith N, Thiravetyan P, Nakajima A, Goodman BA (2010) A reinvestigation of EXAFS and EPR spectroscopic measurements of chromium (VI) reduction by coir pith. Journal of Hazardous Materials180: 759763.
11. Suksabye P, Nakajima A, Thiravetyan P, Baba Y, Nakbanpote W (2009) Mechanism of Cr (VI) adsorption by coir pith studied by ESR and adsorption kinetik. Journal of Hazardous Materials 161: 1103-1108.

12. Suksabye P, Thiravetyan P, Nakbanpote W (2008) Column study of chromium (VI) adsorption from electroplating industry by coconut coir pith. Journal of Hazardous Materials160: 56-62.

13. Suksabye P, Thiravetyan P, Nakbanpote W, Chayabutra S (2007) Chromium removal from electroplating wastewater by choir pith. Journal of Hazardous Materials 141: 637-644.

14. Aworn A, Thiravetyan P, Nakbanpote W(2009) Preparation of $\mathrm{CO}_{2}$ activated carbon from corncob for monoethylene glycol adsorption. Colloid and Surfaces A: Physicochemical and Engineering Aspects 333: 19-25.

15. Twardowska I, Kyziol J (2003) Sorption of metals onto natural organic matter as a function of complexation and adsorbent-adsorbate contact mode. Environment International 28: 783-791.

16. Ventakaraman S (1959) Evapo-transpiration as a agronomic factor. Unesco/NS/AZ/460, Madrid Symposium Paper No.24, August 24: 1-8.

17. Prasad MNV (1995) Cadmium toxicity and tolerance in vascular plants. Environmental and Experimental Botany 35 (4): 525-545.

18. Li D, Zhou D (2012) Toxicity and subcellular distribution of cadmium in wheat as affected by dissolved organic acids. Journal of Environmental Sciences 24 (5): 903-911.

19. Dong J, Mao WH, Zhang GP, Wu FB, Cai $\mathrm{Y}(2007)$ Root excretion and plant tolerance to cadmium toxicity - A review. Plant Soil Environment 53 (5): 193-200. 